\title{
Cultural Diversity and the Somali Conflict: Myth or Reality?
}

\author{
Abdulahi A. Osman
}

\section{Abstract}

The current conflict in Somalia has proven to be long and devastating to its people where thousands were killed, raped, robbed and made refugees or internally displaced. Despite its deadly impact, the conflict has defied all expectations both theoretical and practical. However, there are several studies that attempt to explain the conflict and its causes. These causes include the role of cultural diversity in both bringing and maintaining the conflict in Somalia and Africa in general. This article argues that despite the existence of many studies that emphasise this relationship, they remain empirically inconclusive. The Somali society consists of many communities that differ linguistically and socio-economically. Despite their differences, the conflict in Somalia and Sub-Saharan Africa in general stems primarily from inequality worsened by economic decline

\footnotetext{
* Parts of this article have appeared in earlier publications and presentations by the author. The author would like to thank many people especially Gerard Hagg, Kidane Mengisteab, Mohamed H. Mukhtar and all who played any role in completing this article. The article is dedicated to the many thousands of Somalis who lost their lives or loved ones, and to those who have been impoverished by the mindless and unending conflict that is engulfing their country.

** Dr Abdulahi Osman is an Assistant Professor at the Department of International Affairs and the African Studies Institute at the University of Georgia, Athens Georgia.
} 
plus the easy availability of weapons that resulted from the massive sale of arms by members of the armed forces. The article concludes with several suggestions for bringing about resolution to this prolonged conflict in Somalia. One of the main suggestions would be an attempt to attract the vast wealth and brain power of the Diaspora communities.

\section{Introduction}

The majority of the armed bandits in Somalia often act on behalf and under direction of brutal warlords battling for the control of the state. The bloodbath that resulted from this brutal power struggle, as well as subsequent droughts, claimed thousands of lives, created thousands of refugees outside the country and displaced thousands internally.

Despite this human catastrophe and suffering, the literature on the causes of Somalia's conflict remains inconclusive. The conflict has been explained as stemming from the problem of governance and bad leadership (Samatar 1993; Samatar 1994; Hashim 1997), from the problem of resources (Kusow 1994; Mukhtar \& Kusow 1993; Besteman 1999; Casanelli and Besteman 1996) or from bad economic policy and lack of sustainable development (Osman 2007; Mubarak 1996). Other analyses portrayed the Somali conflict as 'continuing from Stone Age ancestral clan rivalries', but using 'Star Wars military violence' (Besteman 1999:4).

Most of the literature that examines conflicts in Somalia and the region in general give 'ethnicity' and 'contested identity' priority. Specifically, the literature concentrates on 'ethnicity' or 'ethnic-primordialism' as the main cause (Gurr \& Harff 1994; Horowitz 1985). Over the years, however, a number of scholars have questioned the validity of such a causal link (Eyoh 1995; Adedeji 1999; Mamdani 1996; Braathen et al 2000). This article argues that ethnicity is indeed an important factor in explaining these wars, but in a specific manner not yet adequately addressed in the literature. It is insufficient to establish that often the members of the warring factions belong to different ethnic, clan or tribal groups. What must rather be explained, is why the warring factions are fighting. 
This article examines the Somali conflict and the role that cultural diversity played in bringing and maintaining the conflict. In addition to social, ethnic, economic and political factors, Somalia's location has been a central factor in these conflicts. Many forces, both inside and outside the region, have always desired to control the strategic crossroads located in Somalia. Over the years these forces have been attempting to influence the Somali political systems. These forces include the Kingdom of Oman, the Mamluks of Egypt, several European empires during the $18^{\text {th }}$ and $19^{\text {th }}$ centuries and the superpowers during the $20^{\text {th }}$ century Cold War (1945-1990). At the end of the Cold War in 1990, Somalia unfortunately descended into chaos. And since then the continued supply of fresh weaponry has further exacerbated the precarious situation of the country. Thus, the combination of social, economic and political factors along with the available weaponry has prolonged the Somali conflict.

This article concentrates on internal factors, specifically the role of cultural diversity, in both bringing and maintaining the conflict for the past 16 years. But, the article argues that despite the existence of the tribal/ clan differences that are competing for the control of the state institutions; the Somali conflict resulted from three interrelated factors: inequality, economic decline of the 1980s and availability of weapons in the country. The article will be divided into four parts. The first part examines the causes of the Somali conflict. The second part examines the role of the cultural diversity in the Somali conflict. The third part examines the potential role that cultural diversity can play in the resolution of the Somali conflict. Finally, concluding remarks will be offered.

\section{The causes of the Somali conflict}

The causes of the Somali conflict have their roots both in local factors, including social, cultural, economic and political traits of the Somalis, and external factors, including the geo-political and strategic desire of powers from inside and outside the region. Since its beginning, however, the causes of the internal war in Somalia have remained a mystery for both 
Somalis and non-Somalis. The central question is, as Professor Ahmed Samatar (1993:69), one of the leading scholars in Somali studies, brilliantly put it as '... why and how could this society, one of the few nations in the continent with one ethnic group, one culture, one language, and one religion, find itself in such parlous circumstances - verging on self destruction'.

There are two explanations that are offered. On the one hand, Professor Samatar and others explained the internal war in Somalia as one that is stemming from:

- The characteristics of human nature oriented towards a 'historical livelihood' (Samatar 1993:69).

- The collapse of the 'public space and institutions', coupled with the political and economic failures of the former regimes, especially that of Siad Barre.

- The longevity of Barre's dictatorial regime that created 'myriad defects and antipodal propensities of anti-regime groups and forces' (Samatar 1993:60-70).

- The lack of planning on the part of the anti-regime forces.

In short, Professor Samatar and a great number of scholars explained the Somali conflict as coming from a colonial legacy, militarism, anarchy, political struggle, tribalism and other related factors.

On the other hand, there are scholars who argue that the causes of the Somali civil war go much deeper than the explanations mentioned above. According to them, the main causes of the Somali conflict are attributable to the traditional socio-economic mode of production of the Somalis, which is pastoralism or agro-pastoralism (Kusow 1994:25). The Somali society, according to these scholars, can be divided into two groups, which differ in language, culture, and most of all in mode of production. Therefore, the conflict in Somalia stems from '... conflict/ competition between Daroods and Hawiye for the control and domination of the inter-riverine region' (Mukhtar \& Kusow 1993:2). Still others 
blame Somalia's geo-political location, which regional and world powers have regarded as strategically important. First, it is in close proximity to the all-important oil production centres of the Middle East. Secondly, it controls the important trade route through the Suez Canal and the Red Sea. Over the centuries Somalia received military and economic aid from these powers.

The above contradiction is an indication as to why Somalia's civil strife is a mystery, and indeed why it is prolonged. These scholars fall into two schools of thought: homogeneous and heterogeneous. The homogeneous school assumes that the Somali people originated from Southern Arabia, that they share language, culture and common ancestry, that they subscribe to Islam, engage in camel nomadism, and especially that, unlike the rest of Africa, Somalis have been considered a nation. ${ }^{1}$ This school became the standard among the scholars and students of Somali studies, and among the successive Somali governments from 1960 to 1991, the majority of which came from the nomadic clans of the Mudug and Majertinia regions. ${ }^{2}$

The heterogeneous school, on the other hand, assumes that the Somali society consists of settled as well as unsettled communities. This school points to the existence of communities that practice farming, fishing, ironwork, a mixture of farming and herding, trading, etc. in the country, specifically in the southern part (Kusow 1994:27-28). Also, this school argues that Somalis are a multi-lingual society where other languages such as Maay, Jiidu and Dabarre are spoken (Mukhtar 1989; Ahmed 1995).

1 For a similar idea see Laitin \& Samatar 1987 and Samatar 1988. This line of thought is the most accepted. This does not mean that other lines of thought were non-existent, but they were never encouraged or were even totally ignored.

2 At independence the news on radio Mogadishu was broadcasted both in Maay and Mahaa languages and by 1961 the government decided to use only Mahaa, which was the language of the ruling clan. The glorification of their culture and language continued. One example is the creation of the Department of Culture in the Ministry of Education during the 1960s. During the 1970s this department was elevated to the Ministry of Culture and Higher Education. The main idea behind this department was to collect and promote the nomadic cultures. See Mukhtar 1989. 
In fact, I. M. Lewis (1980:5) described the difference between the Maay and Mahaa languages as 'to the same extent as Portuguese and Spanish'. This issue, however, has become a point of contention among the students of Somali studies. In 1994 Professor Samatar mentioned in a footnote the existence of other languages in Somalia, but he insisted despite their existence - that Somalis are homogeneous (Samatar 1994). Professor Samatar went on to say that the homogeneity of the Somali people 'is more than defensible'. In light of the explanations offered by these two schools, the question is then: What is the root causes of the Somali conflict? Before we address this question we need to put the Somali conflict in perspective since it began in 1991.

Since 1991, the Somali internal war has had several observable patterns.

- First, there is the concentration of the war in the southern part of the country. The inhabitants of this area continue to carry the bulk of the death and destruction of the war.

- Second, the inhabitants of the most fertile parts of the country became the majority of the victims of this man-made starvation in Somalia. This was due to the looting of their reservoir, keeping them from all productive activities and finally blocking and looting the food and medicine that were provided by the international donor community in 1992. This blockage and looting caused millions of southern Somalis to die from this man-made starvation, and eventually this area was named the triangle of death.

- Third, the overwhelming majority of the warring factions, including the recent Islamic Courts and Transitional government, are from the nomadic clans of Mudug and Majertinia regions (Osman 2006). In light of this background and perspective then, the question is what are the main causes of the prolonged internal war in Somalia? 


\section{Genesis of the Somali conflict}

This paper argues that internal wars in Sub-Saharan Africa in general, and Somalia in particular, resulted from three interrelated factors, all of which exist because of actions by the colonial and post-colonial states as they responded to the whims of the international political economy.

1. The social inequality that was brought about by the colonial and postcolonial states has been extracting the country's wealth. This extraction was accomplished either directly through state-owned enterprises or indirectly through domination of the country's economic activities. The successive Somali governments created patrimonial paths to state benefits and became the creators and enforcers of social inequality within the society. The beneficiaries of this unequal distribution of state benefits in Somalia are advantaged on the basis of clanism, tribalism and regionalism. The result has been a decline in investment in social capital such as healthcare and education, and an increase in political instability and poverty.

2. The economic decline in the mid-1980s that resulted from among other things the reduction of the economic aid, which funded these states throughout the 1960s and 1970s, and the end of the Cold War in the late 1980s. The result was the disappearance or diminishing of the large and corrupt central government's ability to maintain its reciprocal relation with the various groups (usually the relatives of the ruler) in the country.

3. The access to weapons among the civilians, which occurred when civilians turned to weapons as a mode of survival and defence during the disparate economic times of the 1980s. The abundance of the weapons was the result of Somalia's hyper-militarisation since independence, coupled with the armed forces who were impoverished by the economic decline and rampant inflation of the 1980s.

The following section explores the impact of these three factors on Somalia's internal war. 


\section{Inequality and the Somali conflict}

According to the British anthropologist I.M. Lewis and many others, the Somali society could be described as fundamentally egalitarian and democratic. Lewis (2007) argues: 'Traditionally, decisions are made by councils of men. These councils are egalitarian... Somali egalitarianism permeates all aspects of society. In Somalia, it is not at all unusual for a poor and uneducated nomad to approach a high government official as an equal and engage him in a discussion about the affairs of state.' However, in contradiction to this, Lewis (2007) goes on to say: 'While Somalia's political culture is basically egalitarian, social and political changes have created new patterns of social life. In recent years, a new urban group educated in Western-type schools and working as merchants or in government has emerged. These urbanites enjoy more wealth, better access to government services, and greater educational opportunities for their children than do other sectors of society.'

In the above paragraph Lewis establishes the existence of both an egalitarian as well as a stratified society in Somalia. The question is then who are these Western educated elite who enjoy the disproportional access to wealth and influence in this 'egalitarian' society? A careful review reveals that some groups disproportionately make up the majority of this elite club. As already mentioned, the arena in which Somalia's inequality and social exclusion function, is that of clanism and tribalism. It is evident that the Somali political and economic arena has been dominated by the nomadic clans of the Mudug and Majertinia regions since independence. ${ }^{4}$ The members of these clans made up the majority of the ruling class throughout the short-lived Somali state (1960-1990). Moreover, the members of these clans are at the forefront of the devastating current internal war in Somalia.

3 Lewis 2007 http://www.culturalorientation.net/somali/ssoc.html

4 Please note that these regions are based on the six regional administrations that Italian colonialists used, which the government of Siad Barre (1969-1990) sub-divided into smaller regions. Also, parts of the former Majertinia region were renamed as the Northeastern region. 


\section{The Italian colonial state and its impact on the Somali state}

Colonial administrations provided the blueprint for the post-colonial states in Africa. Italy has specifically been the precursor of the failed Somali state by recruiting its future ruling elites. These elites were not recruited for their ability to develop the political, economic and social interests of the Somali people but were rather selected, as in many colonial states, for their contribution to the efficient functioning of the extractive colonial state. Therefore, historicism and the loaded dice analogy (implicitly or explicitly) established the Somali post-colonial political and economic structure, and the subsequent conflict that followed after 1991.

The seeds of the current suffering in Somali were planted at the end of the 19th century when the European colonial administrations of the British, the Italians and the French were established in Somalia. For the purpose of this paper, however, we will specifically examine the impact of the Italian colonial administration and its contribution towards establishing the current clan hierarchy of the country. Italy first established its authority in Somalia in 1889 when it created a small protectorate in the central zone. Italy expanded to the south and northeast, a territory deserted by the Sultan of Zanzibar. In 1925, the Jubaland treaty was signed, which detached the area east of the Juba River from Kenya to become the westernmost part of the Italian colony. In 1936, Italian Somaliland was combined with Somali-speaking districts of Ethiopia to form a province of the newly formed Italian East Africa. During the Second World War, Italian forces invaded British Somaliland. The British, however, operating from Kenya, retook the whole region in 1941, including Italian Somaliland, where it ruled until 1950.

Italy renounced its claim to the rights and titles of the territory in 1947 under Article 23 of the 1947 peace treaty. On November 21, 1949, the General Assembly of the United Nations adopted a resolution recommending that Italian Somaliland be placed under an international trusteeship system for 10 years. Italy, using tremendous local manoeuvres, won this trusteeship and the General Assembly granted Italy the 
authority to administer its former Somaliland territory. ${ }^{5}$ Italy established the Amministrazione Fiduciaria della Somalia (AFIS) which led to Somalia's independence on July 1, 1960. Immediately the northern British territory of Somaliland, which gained its independence on June $26^{\text {th }}, 1960$ joined the South and formed the Somali Republic. ${ }^{6}$

During its administration, Italy promoted the members of the nomadic clans from the Mudug and Majertinia regions as the local elites. One main reason was that the Italians needed agricultural products which were available in the south. Therefore, Italy created a system that helped them to effectively fulfil their exploitative ambitions, while at the same time using as little Italian manpower as possible. Italy established a patrimonial path to state where they hired the members of the Mudug and Majertinia clans to fill up the lower and mid-level jobs. ${ }^{7}$ Such promotion of clan members from these 'chosen' regions forced the southern agrarian communities to pay heavily for the extractive colonial and post-colonial states. Additionally, this extractive nature of Somalia's governance has further spilled over into the anarchy that followed the collapse of the state in 1991.

Inequality and the politics in Somalia since 1960

As argued, Somalia's elites are overwhelmingly from Mudug and Majertinia regions despite the fact that these clans are minorities in number. ${ }^{8}$ In 1960 Somalia established a unitary government with a

5 For details on the Italian manipulation during this period, see Mukhtar 1989.

6 This union has been broken since 1991 when the former British colony of Somaliland declared its separation. However, this breakaway republic has yet to receive international recognition.

7 This system was used extensively during the colonial era. A case in point is the Hausa's political domination of Nigeria. For details on this practice, see Rodney 1977.

8 Please note that this is based on the 1958 census, which is the only census available. This census showed a total population of 1,263,584 and was based on the entire Italian Somaliland's six regions: Majertinia 82,653 (7\%), Mudug 141,120 (11\%), Hiiraan 176,528 (14\%), Banadir 387,600 (31\%), Upper Jubba 362,234 (29\%) and Lower Jubba $113,449(9 \%)$. This makes the Southern regions of Hiiraan, Banadir, Upper and Lower Jubba the majority with $82 \%$ of the population. For details on the 1958 census, see 
parliament that had 123 members from all the regions of the country at the time (eight, including two regions from British Somaliland). The government had a President and a Prime Minister who in turn appointed the cabinet. During the years between 1960 and 1969 the dominance of the Mudugian clans was clear. For example, members of these clans who occupied the posts of president and cabinet ministers between 1960 and 1969 were roughly two-thirds compared to the one-third occupied by all the other clans.

On October 21, 1969, army units took over the control of the government. The commander of the armed forces Brigadier General Mohamed Siad Barre assumed leadership (although he is not regarded as the author of the military takeover) of the officers who deposed the civilian government. President Siad Barre, himself from Mudug region and a member of the elite clans, installed a governing body, the Supreme Revolutionary Council (SRC), and became its president. The SRC arrested and detained leading members of the government, including the late Prime Minister Mohamed Ibrahim Igaal. ${ }^{9}$ The SRC banned all political parties, abolished the National Assembly and suspended the constitution.

The regime identified itself as a Marxist revolution that adopted the radical transformation of Somali society through the application of 'scientific socialism. The regime promised, among other things, an end to tribalism, nepotism, corruption and misrule. The new motto became: maxaa taqaan and not ayaa taqaan, which means 'it is what you know', and not 'who you know'. Immediately in 1970, the government of Barre

Mukhtar 1989:26. These regions remained intact until the Barre regime (1969-1991) subdivided them into eighteen regions. This division was mainly intended to create administrative enclaves for the Mudugian clans and facilitate the Darood expansion to Southern Somalia. For example, the Upper Jubba region was divided into Baay, Bakool, Gedo and parts of current Middle Jubba region. Specifically, the Gedo region was created for Barre's Marehan clan. The capital city for the region was made a town called Garbaharrey - a small, mountainous and literally empty town - instead of the larger city of Bardhere, a boom city on the banks of Jubba river that has a very long history that is estimated at over 500 years.

9 Mohamed Ibrahim Igaal later became the president of the breakaway Republic of Somaliland. 
organised a huge public rally, where a dummy symbolising tribalism was burned and buried. However, Barre established a totalitarian regime complete with indisputable absolutist power. His regime constituted an even more polarised clan-based structure than the previous regimes. For example, Barre's first cabinet in 1969 consisted of 14 ministers of which seven (or $50 \%)^{10}$ were members Barre's Darood clan. As time progressed this domination became even blunter.

The overall domination of the Mudugian clans in the Somali politics has been clear through the years. For example, between 1960 and 1990 there were 26 governments that nominated a total of 567 posts. The Darood clan took 216 posts, Hawiye 125, Isaaq 102 and Digil and Mirifle 31. This domination was also clear in the individuals that were nominated for government posts. For example, there were 155 individuals that made up the ruling elite in Somalia's government including president, vicepresident, prime minister, and ministers. The members from the Darood clan and their sub-clans made up $62,{ }^{11}$ followed by the Hawiye with 36 and Isaaqs with 30 (see figure 1). This domination of the nomadic clans continues in post-1991 Somalian politics. For example, 11 out of the 15 warlords that attended the talks in Addis Ababa, including the late General Mohamed Farah Aideed, are from the Mudug region. Additionally, the leaders of the current political formation in Somalia, the Islamic Courts under Shekh Dahir Hassan Aweys and the transitional government under Colonel Abdulahi Yusuf Ahmed, are members of the Mudug clans. Despite the apparent inequality that continues in Somalia, social inequality alone does not explain why conflict in Somalia started and continues to bring misery to its people.

10 Up from 32\% in the government of the late Abdirsahid Sharmaarke (1967-1969).

11 Including two prime ministers - in 1967-69 under the late President Sharmaarke and in 1990 under Siad Barre. 
Figure 1: The clan and sub-clans of individuals who held posts, including presidents, vice-presidents, prime ministers, and ministers between 1960 and $1990 .{ }^{12}$

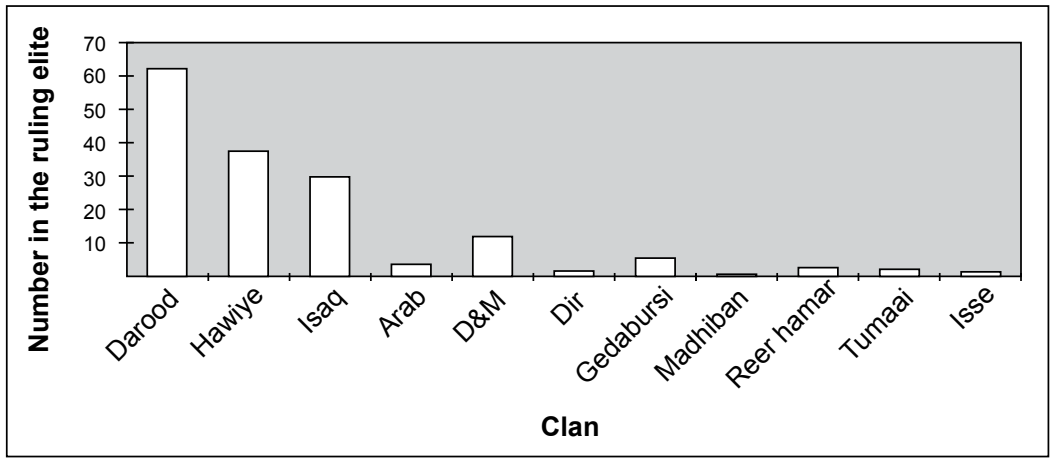

Source constructed from Hagi \& Hagi 1998:118-131.

\section{Economic decline}

The economic decline in most African states, including Somalia, has resulted from social inequality coupled with the reduction of international donations during the 1980s. Over the years Somalia has been the darling of the international Donor Organisations. This was partly the result of the ideological war between the East and West during the Cold War. The Somali ruling elites over the years had received millions of dollars in foreign aid from various donors, which maintained their control of power for more than three decades. For example, between 1965 and 1987, despite the fact that the country's economy had stagnated, Somalia received over US \$ 800 million from the United States (U.S.) alone (Ayittey 1994:3). The main reasons for the stagnation were corruption and the misguided economic policies of the various governments run by the regional and clan-based elites.

International aid had given the Barre regime the ability to maintain its grip on the state and keep the challengers at bay. Somalia, because of its

12 D \& M signifies the clans of Digil and Mirifle 
strategic location, had been a magnet for the combatants of the Cold War (1945-1990). The port city of Berbera on the Red Sea has been, in specific, a point of contest and money machine for the regime. The former Soviet Union first established a naval base in the area and in return provided plenty of military hardware for the regime, thereby making Somalia's military one of the strongest armies in Sub-Saharan Africa. However, in 1977 during the Ogaden war between Somalia and Ethiopia, the Soviets switched their alliance to Ethiopia. The regime then turned to the U.S. for help. In 1980 the Carter administration promised supports for Barre on the condition that he would severe all relations with the Soviets. During that same year Washington and Mogadishu signed an agreement that would allow the U.S. navy to use the naval facilities at Berbera in exchange for military and economic aid. The Carter administration provided a package of about US $\$ 45$ million, which consisted of military, economic and budgetary support.

The Barre regime also received aid from its former colonial power, the Italian government, through its aid agency Funda Aiuto Italiana. Italy invested more than one billion dollars in various projects, but the majority of these projects were wasteful and misguided. Among the many projects was the over US \$250 million spent on the $450 \mathrm{~km}$ road in the sparsely populated and barren desert area between Garowe and Bosaaso (Ayittey 1994:3). The funds from these projects had been spent in a very wasteful and corrupted fashion and ironically the Italian government was aware of it. According to Italian Embassy in Mogadishu employee: ' $T$ The] Italian aid program was used to exploit the pastoral populations and to support a regime that did nothing to promote internal development and was responsible for the death of many of its people' (Ayittey 1994:3). This aid increased the inequality among the Somalis. For example, the number of luxury cars in Mogadishu increased, where it was not a surprise to see a Mercedes or a Toyota Land Cruiser in the streets and markets. More importantly was the increase in the number of luxury houses complete with swimming pools, air conditioners and all modern amenities. In fact, a whole area in southern Mogadishu where huge luxurious houses 
were built by the elites became known as 'Booli Qaran' meaning 'stolen public money'.

By the end of the 1980s, however, the large amount of aid that went to many African states, including Somalia, was devastating to their already weakened economies. ${ }^{13}$ Keen (1998) argues that poor social service and poverty fuel conflict from below. Historically, poor parts of the society tend to turn towards banditry and other illegal activities. For example, in the late 1980s the city of Mogadishu has seen an unprecedented increase in the number of bandit groups and unruly teenagers from the poor parts of the city. One such group was a gang of former orphan children named Ciyaal Faay Cali, 'the children of Faay Ali.' ${ }^{14}$

The dissatisfaction that results from social inequality can become violent and may often lead to larger society-wide conflicts when it is accompanied by economic decline (internal or external) in the society. Bayart (1993)

13 Foreign aid has proven to be a burden on many African economies. During the decade of 1970s and 1980s many countries opted for the easily available foreign aid and as a result ran into debt. Of the 32 countries with the highest debt, 25 belonged to Sub Saharan Africa. While many view foreign aid as beneficial to the economies of the recipient countries, others argue that aid flow has been disastrous to many developing economies. There are four factors behind the disastrous outcome. (1) Aid flows were generally closely tied to the geopolitical interest of the donor nations, mainly the West. (2) Aid revenue was not directly attached to production and has been continuously provided regardless of the recipient country's productivity or growth, which in turn hindered the incentive for local economy to grow. (3) Autocratic regimes became grant writers that declared what they intended to do with the funds, rather than promoting the country's economic development. Moreover, aid flows helped to increase the 'kleptocracy' among the ruling elite who had access to ready cash and used it for salaries and lavish lifestyles and for maintaining networks of patronage rather than productivity. (4) Aid has always been dependent on the domestic politics of the donor countries, which tend to distort any long-term economic planning and strategies (Brautingham 2000; Leonard \& Straus 2003).

14 The name comes from a lady named Faay Ali who raised a number of orphans. These children reached adolescence during the 1980s, which coincided with the weakening of the Siad Barre regime. The gang was notorious for brutal actions including robbing, raping and even murders. But, importantly, they were partially responsible for the dismantling of the regime and the creation of public dissatisfaction and apathy towards the regime. This is based on an interview the author conducted during 1993-94 in Mogadishu. 
argues that in the conditions of extreme poverty, scarcity, insecurity and political instability that exist in Africa, everyone is engaged in life-anddeath struggles, both to survive and to accumulate wealth and power. In this struggle both rich and poor strategically attach themselves to networks and organise factions primarily based on one's family, friends, clan or ethnic alliance. This struggle is central to the understanding of political action in Africa. Its objective is the control of 'the distribution of the possibilities of realizing a primitive accumulation, in the strict sense of the concept, by the confiscation of the means of production and trade' (Bayart 1993:234). These factions, whilst engaged in the obtainment of an acceptable livelihood and security, provide the arena in which conflict and violence become more probable. Bayart concludes: 'Today, as yesterday, what is being fought for is the exclusive right to the riches claimed by the holders of 'absolute seniority' (Bayart 1993:241).

Overall, there is little doubt that the number of violent conflicts and internal wars has increased in the poorer countries of the third world. There is also little argument that the increase in the number of these conflicts was severe for Sub-Saharan Africa, coinciding as it was with an era of economic decline due to, among other things, the end of the Cold War. Stewart and Fitzpatrick (2001) assert that the high incidence of conflicts in poor countries results from three interrelated factors: (1) a widening inequality in wealth and income between vertical (social) groups and horizontal (territorial) groups in the country; (2) an increase in the uncertainty of future prospects; and (3) a weakened capacity of the state.

\section{Access to weapons and the Somali conflict}

The economic decline, which resulted both from internal social inequality and from external factors such as the decline in the amount of aid and the enforcement of Structural Adjustment Programs, created an environment of declined security both economically and physically. Military expenditure is an issue of the security for the state. Hutchful (2000:211) argues 
that among other things the state is created as a 'security racket'. He says, 'The relationship between governance and security is at once intimate and obvious. First, governance is both about creating and the management of the instruments of violence that at the same time necessarily underpins assuring conditions of security. Second, governance involves the effective administration, regulation and control of the instruments of violence'. However, Jackson (1992) argues that the security of the states in the post World War II era has been guaranteed by external forces e.g. former colonial powers, cold war superpowers, international and/or regional organisations (United Nations, North Atlantic Treaty Organisation, Economic Community Of West African States, African Union, etc.) and the state is secured from external threat. Despite this minimum external security threat the African militaries expanded tremendously. For example, in 1963 the average African state had 0.73 soldiers per 1000 people, but by 1979 this figure had jumped to 3.10 per 1000 people (Herbst 2000:105). Therefore, over the years the state militaries became palace guards and a tool for the ruling elite to dominate the rest of the society.

The rulers of most post-colonial states in Africa have used the military as a reward for their clansmen. For example, in Kenya the Kamba and Kalenjin made up 34\% of the Military in 1963, while these clans together accounted for only $9-11 \%$ of the total population. Also, in the same year in Nigeria, there were a total of 81 officers and 60 of them were Ibos (Odetola 1982). During Siad Barre's regime (1969-1991), the Somalia security apparatus was controlled by three groups: the Marehaan, which are Barre's clan, the Ogaden, his mother's clan and the Dhulbahante, his son-in-law's clan, who all fall within a larger clan family of Darood, an alliance labelled among the Somalis as MOD (Laitin \& Samatar 1987). Over the years this large and tribalised military created an insecurity dilemma, where the average citizen was afraid of the military of his/her own country. Additionally, military expenditure dragged the economies of Sub-Saharan African countries to the ground. The result was that the responsibility for the security and welfare of individuals and groups 
that were not part of the military or the bureaucracy fell to other social organisations such as clans or clan and kinship groups. There is no place where this issue was as grave as it was in Somalia.

Since its independence, Somalia received great attention from the combatants of the Cold War: the former Union of Socialist Soviet Republics (USSR), and the US, which showered the country with huge supplies of weapons. Somalia always had a great appetite for weapons which was then matched by the willingness of the superpowers (during the Cold War) and regional powers (such as Egypt) to satisfy this demand. Since its independence in 1960, different Somali governments engaged in a policy of hyper-militarisation. Somalia spent an average of $20.45 \%$ of its budget on the military between 1960 and 1990 and had an average of 8 soldiers per 1000 of the population, well above the regional average of less than 4 per 1000 (Osman 2007). Between 1960 and 1990 Somalia's military grew steadily despite being one of the poorest states in the world. For example, the military expanded from 5,000 troops at independence in 1960 to 65,000 in 1990 (Lefebvre 1991).

Somalia's hyper-militarisation was greatly affected by its location, which is of great geo-political and strategic interest to the regional and great powers. During the early 1970s, the Soviets were allowed to establish a naval base at the strategic northern coastal city of Berbera, located at the entrance of the Red Sea. This was made mainly as a reaction to the largescale American military support of Somalia's rival Ethiopia. During the war between Ethiopia and Somali war in 1977-1978, superpowers switched their allegiances. Soviets became allies of the Marxist regime of Col. Mengistu Haile Mariam of Ethiopia (1974-1991), while the U.S. became an ally of Somalia. Between 1979 and 1990 the U.S. sent hundreds of millions of dollars worth of arms to Barre's regime in return for the use of military facilities at Berbera (Ayittey 1994; Lefebver 1991). In addition to the support from the superpowers, the country also received military support from Arab countries, China, West Germany, Italy and Apartheid South Africa (Ottaway 1982; Lefebvre 1991). 
In January 1991, Siad Barre's 21-year reign finally ended and Somalia descended into full-scale internal war. The Somali internal war had been in the making for several years. It resulted from a combination of several factors - local and international - and involved many different actors. At the national level, several years of continued frustration over basic human needs caused social unrest. Additionally, the government's ineffective policies created economic stagnation and brought about extreme poverty. Moreover, this decline made the government unstable as evidenced by the constant cabinet reshuffles, defections, loss of state authority and, worst of all, it politicised the armed forces. The difficult living conditions in turn created an incentive for young men to join factional militia that were opposed to the government of Siad Barre.

The economic hardship of the 1980s facilitated the transference of weapons to the public. Thus, by the beginning of the war in 1991 law and order immediately became non-existent and Somalia descended into total chaos. The chaos was further exacerbated by the failure of the international community to resolve the conflict at its early stages. All international organisations, including the UN and NGOs, and all diplomatic missions pulled out from the country. Regional organisations did not help either. Somalia is a member of the Organisation of Islamic Conference (OIC), the Organisation of African Unity/African Union and the Arab League but unfortunately not one of them had the capacity or the willingness to interfere. It took several thousands of Somalis to die, millions of dollars worth of property to be destroyed, and millions of refugees to show up in the neighbouring countries and as far as Canada and USA, for the west to come to the rescue. The Somali warring factions were left alone to fight and destroy the infrastructure of the country. In 1992 the UN Security Council passed Resolution 733 which called for an embargo on weapons and military equipment being sent to Somalia. However, since its passing, this resolution had become one of the most violated resolutions as Somalis kept 
receiving fresh supplies of weapons from Arab and Ethiopian sources in clear violation of the embargo. ${ }^{15}$

The high military spending led to an economic slow-down in many Sub-Saharan African countries. As a country's economy declined it led to declining security and a leak of weapons through sale and theft into the hands of civilians. Where the bad economy is coupled with the availability of arms, the state becomes weaker and incapable of providing security (physically and economically), and this may lead to chaos and possibly the collapse of the state. As the central power weakened, and in some cases collapsed, the emerging groups must pay attention to their power relative to other groups. Power struggles ensue as these groups prepare and pool their resources in order to preserve their existence. These groups must organise themselves, choose leaders, set up bureaucracies to collect taxes (or sometimes loot others) and organise security forces in order to enforce internal cohesion and military forces to insure external security (Posen 1993). The power resources of the old regime, especially materials (e.g. weapons, money) and contacts (e.g. diplomatic relations), then become spoils for the contesting groups. For example, in the Somali internal war, the clans that had heavy representation in the military and the administration were best positioned to benefit from the disintegration of the state, both materially and politically. These groups were mainly from the clans of Mudug and Majertinia, in other words Darood and Hawiye. Overall, the conflict in Somalia resulted from the proliferation of weapons during the Cold War and the continued supply

15 Time and again the Security Council revisited the observance of the resolution and came to the same conclusion. As early as July 1992 the violation of the resolution and the frustration of UN Secretary-General Boutros Ghali were apparent. For example, a report he furnished on 22 July 1992, says: ' $\ldots$ the situation regarding the flow of arms and ammunition from outside and the continuing use of military weapons on a large scale inside Somalia had not changed since the last report.' (S/24343). This violation has been repeated several times since Boutros Ghali's report. A report furnished by the UN in November 1993 states: 'Major violations of the arms embargo against Somalia have taken place over a six-month period, but the weapons now arrive continuously in many small quantities, while large quantities arrive less often, a monitoring panel has told the United Nations Security Council.' 
of weapons after 1991, which ignited and continues to ignite the war efforts among the grieving Somali clans.

\section{Somalia's shared cultural values and heritage}

Earlier we have established the existence of two schools of thought in Somalia: homogeneous and heterogeneous. Depending on which school one subscribes to, one's conclusion is predictable. Somalis speak 13 living languages including Jiddu, Dabarre, Boni and Garre. ${ }^{16}$ However, the overwhelming majority of Somalis speak the Maay and Mahaa languages. Despite the description of Somalis as a monolingual society, the speakers from each of these two languages are not intelligible to each other. In spite of this fact, however, I.M. Lewis, founder of the Somali homogeneous school of thought, described the difference between these two languages as similar to the difference between Portuguese and Spanish (Lewis 1980:5).

Closely following linguistic differences is the role of the clan. The Somali society is divided into six major groups who speak two distinct languages. These are (1) Hawiye, Dir, Darood, and Isaaq who are overwhelmingly nomadic and speak the 'Mahaa tiri' language, and (2) Digil and Mirifle who practice agro-pastoralism (a mixture of dry farming and herding) and speak the 'Maay' language. Additionally, there are smaller clans that include Bantu, Arab and Persian descendents.

The southern settled communities make up the overwhelming majority of the Somali population. According to the 1958 census $^{17}$ roughly $82 \%$ of the population of the Italian Somaliland live in the area south of Shabelle River. The Italian colonial administration divided the country into six administrative regions. These regions remained intact until the Barre regime (1969-1991) further divided them into eighteen regions.

16 http://www.ethnologue.com/show country.asp?name=SO

17 In 1974 the Barre government made another census, but its results were never published. For details on the 1958 census see footnote 9 above. 
This division was mainly intended to create administrative enclaves for the Mudugian clans, specifically, the Darood expansion into Southern Somalia. For example, the Upper Jubba region was divided into Baay, Bakool, Gedo, ${ }^{18}$ and parts of current Middle Jubba regions. But, let's look at the relationship between cultural differences and conflicts.

\section{Cultural diversity and conflict}

The relationship between ethnic diversity and internal war can be traced back to Aristotle who had suggested that diverse nations are more susceptible to internal conflicts than their homogenous counterparts (Lipjhart 1977). Indeed, ethnicity per se constitutes the critical, if not the determinant, source of conflicts in general and in Africa particularly.

Most of the literature on conflicts gives 'ethnicity' and 'contested identity' priority. Specifically, the literature concentrates on 'ethnicity' or 'ethnicprimordialism' as the main cause of the increased number of conflicts (Gurr \& Harff 1993; Gurr \& Harff 1994; Horowitz 1985). Many internal wars in Sub Sahara Africa are attributed strictly to 'tribal warfare' and many Western analysts attempt to put the causes of these wars and violence on sociological factors inherent to Africa. This school looks at ethnicity as given, so that a person will belong to a group automatically at birth (Kaplan 1993; Connor 1994). The membership of these groups is given whether it is based on clan/tribal lines, e.g. Zulus or Serbs, ${ }^{19}$ or common history, e.g. Italians.

Primordialism is the idea that ethnicity is fixed, fundamental and rooted in the unchangeable circumstances of birth. The primordialist approach asserts that 'the urge to define and reject the other goes back to our remotest human ancestors, and indeed beyond them to our animal

18 See footnote 9 above.

19 Most of the Somalis feel obligated to participate in the tribal opinions and activities, and to contribute money to the fighting. This identification resulted from years of training and preparation by their families and community at large. One is raised to safeguard the tribal norm from infancy. 
predecessors' (Lewis 1992:48). Edward Shills (1957) was one of the first scholars to assert that in the family attachments there are significant relationships that can only be described as primordial. This approach was further elaborated by Clifford Geertz (1973) who describes primordial tendencies as ineffable, with coercive ties, which is the result of a long process of crystallisation. Geertz advanced three major ideas that primordialism is based on:

- Primordial identities are natural or given.

- Primordial identities are ineffable and cannot be explained by other social interaction, but are rather coercive.

- Primordial identities essentially stem from sentiments and affections, rather than from realities of survival.

Geertz's description is based on biologically determined factors which are fixed and unchanging. This school suggests that whenever the need arises (with regard to survival, enhanced economic and security, etc.) people go back to their ethnic identifications in order to achieve their goals. Therefore, implicit in this line of thought is that the fixed and uncompromising politics of identity, characterised by communal exclusivity and tendencies toward xenophobia and intolerance, are natural to human societies.

Other approaches that examine ethnicity view it from an instrumentalist perspective, which looks at ethnicity as an instrument used by individuals, groups or the elite in order to gain more power, mainly material power (Brass 1985; Steinberg 1981). In this approach ethnicity is a multi-purpose tool employed by a variety of elite organisers in order to reach their target. Thus, in the majority of cases in Sub-Saharan Africa, ethnicity happens to be what is available in that setting. For example, in Somalia the warlords have been mobilising their tribesmen for the past 10 years, because ethnicity was the only tool available for mobilisation. Ironically, these combatants, who are organised along clan lines, 
most of the time do not even know what they are fighting for. ${ }^{20}$ So, in this approach, ethnic violence should not be differentiated from other conflicts.

Still another approach views ethnicity as a constructed mythology. This approach bridges between primordialists and instrumentalists. In this approach, ethnicity is neither given as primordialists argue, nor used as an instrument by the few elite, but rather stems from social interactions. ${ }^{21}$ Constructivism argues that individuals belong to a multitude of groups, such as merchants or intellectuals, and eventually to the nation. For example between 1960 and 1990, although Somalis belonged to their particular clans, these groups were still intermingling and working side by side. In fact, it was politically incorrect during this period for one to even ask the clan of another person, especially in the urban areas. This inquiry would earn the asking individual the label of reer baadiye, which means country folk. However, after the collapse of the central government in early 1991 every person, including urban dwellers, was forced to seek security and protection from his/her particular clan (Lake \& Rothschild 1998). Therefore, conflict in this approach results from a '... pathological social system, which individuals do not control... it is the social system that breeds violent social conflict, not individuals, and it is the socially constructed nature of ethnicity that can cause conflict, once begun, to spin rapidly out of control' (Lake \& Rothschild 1998:6).

The deterministic approach, specifically provided by primordialist theorists, suffers from two major flaws. First, they fail to make the distinction between cultural identity and politically relevant cultural identity. They assume that cultural differences, including language, religion and traditions, automatically lead to conflict because culturally defined groups tend to be exclusionary and are dominated by old values that outweigh universalistic norms. According to primordial accounts, parochial norms attributed to cultural groups are believed to isolate them and reinforce

20 This is based on observation in the country's war pattern during my visit 1993-1994.

21 For details on this approach, see Brubaker 1995 and Kuran 1998. 
their extremism. Second, primordialists ignore the role of state institutions in both easing and perpetuating culturally based conflicts.

Over the years, however, a number of scholars have questioned the validity of such a causal link (Eyoh 1995; Adedeji 1999; Mamdani 1996; Braathen et al 2000). This paper argues that ethnicity is indeed an important factor in explaining these wars, as compared to non-war situations, but that ethnicity has not yet been adequately addressed in the literature. It is insufficient to establish that often the members of the warring factions belong to different ethnic, clan or tribal groups. What must be explained rather is why the warring factions are fighting.

Braathen et al (2000:4) suggests that the warring factions must be '.. understood in the light of the socio-economic context in which they operate, and within this context ethnicity is just one among many variables'. While ethnicity is an important factor, the key to understanding what causes internal wars in Sub-Saharan Africa is the attributes of the post-colonial state. They argue that these wars occur not because of the primitive social settings, but rather in the context of the 'power game and the arena of modernity'. This arena of modernity is '.. the state and the fight to gain control of state resources, power and possibilities' (Braathen et al 2000:10). Specifically, the rewards (real or perceived) of capturing and maintaining state power have been a key source of conflict across the continent.

Since independence political conflict in this region was frequently waged in the Zero-sum mode, where the winner takes all. In short, the causes of internal wars involved ethnic identity as it was related to politics and power, rather than mere difference in identity alone. For example, Tanzania has over 100 ethno-linguistic groups, whereas Somalia has about thirteen. Despite its larger diversity, Tanzania over the years managed to maintain relative economic growth and social stability. On the contrary, Somalia with less ethnic diversity experienced internal war and the collapse of its state in 1991. Finally, comparing the countries 
that experienced civil war since 1990 to those that did not the picture becomes even clearer.

Many studies support the view that ethnicity in fact produces stability in many countries. Elbadawi and Sambanis (2000) examined the cause of internal war in African countries and argue that the relatively high prevalence of war in Africa is not due to the ethno-linguistic fragmentation of its countries. They argue that Africa's ethnic diversity acts as a deterrent, rather than a cause of internal war. They empirically examined the relationship between multi-ethnicity and the occurrence of internal war in 32 countries in Sub Saharan Africa that achieved their independence prior to $1975 .{ }^{22}$ Seven of these countries, which experienced internal war in the post-1990s era, had an average diversity of 0.45 whereas twentyfive countries that did not experience internal war had a diversity index of 0.83 (see figure 2 ).

Figure 2: The relationship between ethnicity and war

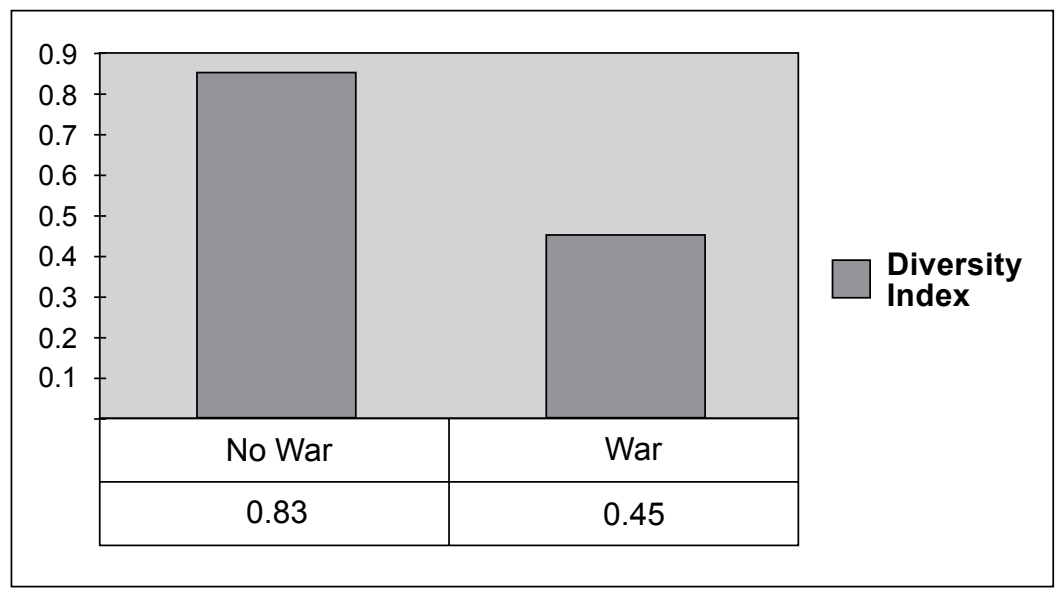

Adapted from Ethnologue 2006 http://www.ethnologue.com

22 Diversity is measured as the probability that a randomly selected two individuals in a society will belong to different groups. The index varies from 0 to 1 . The value is zero for a completely homogeneous country where the probability of belonging to different groups is nil. The value 1 occurs in the hypothetical society where each individual belongs to a different group. http://www.ethnologue.com 
In order to understand the connection between ethnicity and internal wars in Africa, one must examine Africa's ethnicity from the historical context, the institutional structures and the policies that the institutions adopted. The most important historical context in Sub-Saharan Africa is its colonial legacy, which shaped its ethnic structure. Colonialism created and strengthened particularism (divisions based on ethnicity, language, religion, etc.) by creating new 'countries' with artificial boundaries often populated by politicised, suspicious and envious groups (Mamdani 1996; Médard 1996; Braathen et al 2000). The colonial state shaped Africa's present-day ethnic divisions through the demarcation of African linguistic and cultural differences.

In an effort to establish an effective administrative system, colonial states instituted three policies that made cultural diversity relevant to survival of the individuals and groups. First, they made the loose tribal/clan affiliation in Africa into a rigidly demarcated identity schema and in some cases created a system of identity for millions who had previously had no tribal/clan identity (Ottaway 1999; Clapham 1988; Mamdani 2001).

Second, they politicised the identity groups by utilising ethnic structures, at different levels, in both the indirect rule of the British and the assimilationist direct rule of the French (Mamdani 1996; Young 1994). Third, colonial states encouraged local groups to advance their interests through tribal organisations. They sought the patronage of tribal leaders, thereby strengthening ethnic, clan or tribal loyalties. Today, these ethnic divisions are the source of much of Africa's violent politics. Even in places where internal war did not occur, ethnic, clan or tribal divisions typically weakened political institutions and undermined economic growth (Berman 1988). It is this legacy that shaped the structure and policies of the postcolonial African states and provided the basis for the conflicts in many parts of the continent. State power became concentrated in the hands of a few elites and clansmen benefit (often through nepotism and corruption) disproportionately from that power. ${ }^{23}$ As a result, the post-colonial state in

23 For a similar argument, see Chazan et al 1999. 
Sub-Saharan Africa became a highly visible and contested resource, mainly because the members of the ruling clan often received disproportionate wealth and power (Adedeji 1999; Braathen et al 2000). Frederick Forsyth (1977:25) said the following about Africa's post-colonial politician:

In Africa as elsewhere political power means success and prosperity, not only for the man who holds it but for his family, his birthplace and even his whole region of origin. As a result there are many who will go any length to get and having got it will surpass themselves in order to keep it.

\section{Cultural diversity and Somalia's conflict}

We have established that the foundation of the Somali diversity is the clan. The clan, in Somalia, is above every thing else, above political parties, religion and any ideology. Clanism in Somalia represents the primordial cleavages and cultural fragmentation within the Somali society. Clanism is the basis for numerous political and social problems including the current endless conflict. In light of the above narration, I would argue that cultural diversity has played a minor role in the Somali conflict compared to clan membership. Every Somali belongs to a particular clan, sub-clan and family. In this sense the clan is a uniting force and at the same time a great dividing force.

The two main groups among the Somali clans are the nomadic and the sedentary. The most fundamental difference between these two groups is how much value each attaches to the land. The settled communities attach a great value on the land, because they see the land as their source of income and survival. Thus, they do everything to save this land. The nomadic clans mainly look to the land as transient and temporary. Both the nomadic and settled communities have local customary laws (Heer). The nomadic Heer mainly concentrate on conflict settlements (Diya Paying). ${ }^{24}$ The Heer among the settled communities do not only deal with

24 This is a blood compensation for the wrongful killing of a person from another clan. For more details on the Diya Paying system, see Lewis 1955, Lewis 1961, Touval 1963, Laitin \& Samatar 1987, Casanelli 1982. 
conflict settlement, but also with individual and group duties towards the common interest of the village community. For example, the Digil and Mirifle as settled communities established a well organised social and political structure based on hierarchical authority. Homogeneists such as Laitin and Samatar (1987:27-28) have described the hierarchy of the inter-riverine communities as follows: 'Unlike decentralized nomads these communities have a highly centralized and hierarchical social order, whereby for example social pre-eminence is held not by numeric basis, but by virtue of seniority or urad (first born) status.'

The second most important cultural heritage that unites most Somalis is religion. Islam had arrived in Somalia within the 10th Century. The most important method for the expansion of Islam was the Tariqa (way or path) or religious orders. The rise of the Tariqa in Somalia was heavily influenced by the development of Sufism, which appeared in Somalia during the $15^{\text {th }}$ century and rapidly became a stimulating and mobilising force. The main reason for the expansion of Sufism in Somalia was its appeal in providing a closer personal relationship to God through special spiritual disciplines. Many historical figures, including Sayyid Mohamed Abdulle Hassan and the Mad Mullah who fought against the British in the $19^{\text {th }}$ and early $20^{\text {th }}$ centuries, used the Sufi sect of Salihiyya as a mobilising method. Certainly, today's United Islamic Courts (UIC) are using religion as their mobilising method. However, despite the strong ability of religion to mobilise, the clan identity always supersedes all other identity schemas. For example, the recently deposed UIC leaders are overwhelmingly from the Hawiye clan, and specifically the Habargidir sub-clan. Therefore, in evaluating their leaders, the Somalis first ask the clan affiliation of the individual and only then other inquiries, including the qualities of the leader, follow.

Following religion as a uniting factor is the mode of production, which is mainly herding or farming. As we mentioned, prior to the period of colonialism the Somali clan families had for a long time occupied and been restricted to their particular geographical locations. However, due to the highly variable rainfall in some regions, especially the central and 
northern regions, the nomads are often forced to move from one place to another in search of pasture for their livestock (Lewis 1955). The harsh conditions also make it hard for any one family to contain itself in one geographical location. In fact, most of the time all necessary resources to maintain both the clan and its herds cannot be found within any one locale. Over the years, the nomadic clans have therefore devised several inter-clan alliances, treaties and clientships to deal with these difficulties without compromising territorial and geographical boundaries. During the dry seasons, a whole clan can move from its homeland to the land of a neighbouring clan that have available water and grazing and with whom they have a formal treaty. In this situation, the guest clan will acquire the right to remain in the land in exchange for contributing to the collective defence of the host clan.

This type of patron-client relationship also existed between nomads and cultivators. The nomads would often move to areas with more water and grazing where they could enter into client status with the cultivators. In some situations the nomads accept a temporary clientship. In other cases, some of the nomadic clans that have lost their herds find themselves in a permanent subordinate client status. In this situation, the guest is allowed to farm the land without any direct ownership and is required to abide by the rules and regulations of the host clan. ${ }^{25}$ Both the British and the Italian colonial powers would not interfere with the lifestyles of the Somali nomads, especially those in the north. In the south, however, the Italian colonial state settled along the agriculturally rich Shabelle River and used more direct colonial practices including the removal of traditional leaders and forced labour.

The most important figure in the diversity-related conflict of Somalia was the former dictator General Mohamed Siad Barre whose reign was known for its clannish 'divide and conquer' tactics. The government of Siad Barre (1969-1991) created a highly centralised and dictatorial state. Two major reasons helped his regime to achieve this seemingly

25 For a good description of clan treaties and clientship, see Casanelli 1982:75-78. 
cohesive appearance. First, the use of the Somali language since 1972 enabled the government to reach the people through its publications. Second, there were the nominal restriction and even the ban of tribalism, at least at the beginning of his regime. These two policies allowed the Barre regime to spread an ideology of unity and cohesiveness. By 1975 , however, the regime was unable to distance itself from the clanism and tribalism, which together had created and maintained the Somali political organisations for centuries. By the end of the Ogaden war in 1978, several different clans started to voice their disappointment about their status under the Barre regime. One such example was the April 9, 1978 coup attempt (Samatar 1988:138). Immediately, Siad Barre started to ally himself with people from his clan and the Marehaan-OgadeenDulbahante clan-based coalition known as MOD. ${ }^{26}$

Siad Barre's regime was an authoritarian, one-man, rigid and centralised rule, full of rampant corruption, injustice and economic mismanagement. During his 21-year rule, Barre manipulated clan loyalties and rivalries, favoured members of his own clan, and undermined independent sources of authority. In what was to be a recurring pattern, following an April 1978 coup attempt led mainly by army officers from the Majerten clan, Siad's forces singled out Majerten civilians for reprisals. After the creation in 1981 of the Somali National Movement (SNM), a guerrilla force that drew its support from the Isaaq clan, the government unleashed a reign of terror against Isaaq civilians, killing 50,000 to 60,000 between May 1988 and January 1990. ${ }^{27}$

From the outset, Barre's government favoured members of his own clan, the Marehan, who were recruited in large numbers into the army and who were also favoured within the civil service. Despite this favouritism, Barre purported to outlaw 'tribalism' by banning clan gatherings, such as engagement and wedding ceremonies. He manipulated the clan

26 For a good description of how the Barre regime changed its policy from nationalism to tribalism, see Samatar \& Laitin 1984.

27 Human Rights Watch 2006

http://www.hrw.org/reports/1993/somalia/\#P68_12775\#P68_12775. 
structure by corrupting and sometimes creating and legitimising clan elders and making them paid nabad doon or 'peace seekers'. All independent institutions capable of challenging the government's power were destroyed, leading civilian politicians were arrested, independent civic organisations and political parties were outlawed, and any form of political dissent was prohibited. Thus, in seeking to maintain himself in power, Siad Barre fanned the flames of clan animosity while systematically destroying any institution that could cut across clan lines or act as an authentic mediator in disputes between clans.

Siad Barre was also responsible for introducing the strategy of banditry into the civil war, particularly during the 1988 war against the SNM. During this brutal campaign, Barre's troops, many of whom later joined clan factions after the collapse of the central government, were openly allowed to loot and sell the spoils of the war in the markets of Mogadishu with no fear of punishment. This practice broke with traditional Somali customs governing competition between clans and changed the character of the civil war. After Barre's ouster, other clan factions continued these tactics. Dictatorial regime had oppressed people for more than a decade.

When Siad Barre's regime was overthrown, society was overwhelmed by its sudden freedom after more than a decade of dictatorial regime. Unfortunately, however, this freedom was marred by the increased poverty and availability of weapons in the markets which transformed the initial jubilation into an instant and endless nightmare. As Somalis were engulfed by this conflict, tribalism took an uglier turn and every clan created its own political party. In most cases, these parties included the word 'Somalia' in their names and pretended to represent all Somalis instead of one specific clan. 


\section{The positive role of culture in peace making, conflict resolution and post-conflict reconstruction}

Understanding culture and diversity is an important key to unlocking and understanding complex human nature. Acknowledging those that are culturally different can lead to a conscious awareness of how our thinking and actions affect others operating from different perspectives. Despite the fact the Somalis have been described as homogeneous, they do enjoy a rich and diverse cultural heritage. Many earlier and recent expeditions and studies point to the existence of a rich oral culture, and to resilience and creativity among the people. The most relevant aspect of the cultural diversity of Somalis is the use of the local customary laws known as Heer. Both the sedentary and nomadic clans used to mediate among themselves and maintain the rule of law inside the clan as well as in inter-clan relationships. However, as colonialism took root in the country and most of the continent, one of the earliest casualties was this noble institution.

More specifically, the Italians used a direct colonial system that practically destroyed the conflict resolution mechanisms practiced by the Somali clans. They created a pro-Italian cadre, as the French created the evolue and the Portuguese the assimilados. For its own colonial interest Italy recruited its cadre from the nomadic clans of the Mudug and Majertinia regions. Since independence, this pattern continues where the Western educated technocrats dominate the social, political and economic scene of the Somali society. Nevertheless, as Ekeh (1975) argued, these technocrats simultaneously exist in two diametrically opposed camps: one civic and one primordial. In the civic camp they are supposed to function as impartial workers dedicated to the national interest. In the primordial camp, however, they are supposed to be mindful of the interest of the particular clan. This quagmire needs to be understood in order to come up with a proper diagnoses of the causes, and perhaps, with a viable solution for the Somali conflict. 
Once the conflict began, this cadre, who suffered from the dual identity crisis, could not put back together the country they had dragged into the ground. In British Somaliland, however, where the clan culture is relatively intact, mainly due to Britain's indirect colonialism, the local clan elders and leaders saved the day. Their counterparts in the south, on the other hand, continue to be disillusioned and to remain in a second-class position after the confused Western educated cadre.

As argued, the Somali cultural diversity is rich with conflict resolution mechanisms that can be used to end the conflict. However, for the past 15 years the international community has ignored the legitimacy of clan elders and leaders who possess the ability to penetrate the tribal politics and who may get results. On the contrary, the resolution efforts so far have mainly been concentrated in the hands of the warlords. They were given a blank page on which to draw Somalia's future. They met in Ethiopia, Kenya, Djibouti, Egypt, Sudan and currently in Mogadishu, and each time they enjoyed lavish lifestyles. Each time they decided on something the decision was only worth the paper it was written on and the ink that it was signed with. Ultimately, the Somali conflict can only be resolved through its clan structure, by empowering and reviving the legitimate leaders and elders.

As established, for a long time Somalis have dominated each other using the clan as the basis for enforcing their worldviews and advancing their interest in their political system. More specifically, the nomadic clans dominated and continue to dominate the political system of the country. Their perspectives have often been degrading to the sedentary communities in the southern part of the country. In fact, among the nomads, land cultivation, as well as most physical work such leather making and ironwork, is seen as an inferior profession in which only those who have no livestock, especially camel, engage. This rift between nomads and cultivators has been the basis for many conflicts including the current genocide in Darfur, Sudan. Since 1991, over 15 peace conferences were 
convened by the international community, at which tacit acknowledgement was given to the diversity of Somalia.

At the past three peace conferences that were held in Sodere (Ethiopia), Arta (Djibouti) and Mbagathi (Kenya) this reality had to be faced. After two years were spent on the conference in Kenya, which mainly gathered some of the biggest warlords that destroyed the country, a transitional government was eventually produced. In the parliament of 275 members that was to be elected, 61 members were allocated to each of the four large clans ${ }^{28}$ and 31 to a cluster of minority clans. The parliament elected Sharif Hassan Shekh Adan from the Asharaf clan, a sub-clan of Dighil and Mirilfle, as the speaker and a former warlord, Colonel Abdulahi Yusuf Ahmed from the Mejrteen sub-clan of Darood, as president. The President in turn appointed a 51 year old from the Abgaal clan, a sub-clan of Hawiye, Ali Mohamed Gedi, as prime Minister. Mr. Gedi appointed a 41 member cabinet, the majority of which happen to be the strongest warlords in the country. Additionally, the new constitution accepts the existence of two languages, Maay and Mahaa, as official languages in the country.

Despite the fact that diversity has been acknowledged, the domination of the political power by the nomadic clans is however still apparent. For example, the current transitional government is headed by Colonel Abdulahi Yusuf Ahmed and the defence minister, police commander; and foreign affairs minister are all from his clan of Darood.

\section{Conclusion}

This article examined the role of cultural diversity in initiating, maintaining and potentially resolving the prolonged conflict in Somalia. The Somali conflict primarily resulted from inequality, economic decline and availability of weapons. The conflict was initiated by clans who cited the existence of an inequality that preferred certain clans to others. Despite

28 Darood, Dighil and Mirilfe, Hawiye, Isaaq and Dir 
the existence of such inequality since the country's independence in 1960, the internal war started in 1991. The beginning of the war, however, followed the economic decline of the 1980s, which in turn facilitated the transference of weapons to the grieving clan members. The remaining question now is what, if any, resolution can be offered in order to bring Somalia's prolonged conflict to an end.

Somalia has two positive aspects that can enhance its rebuilding once the conflict ends. First, contrary to what has been published, Somalia is endowed with natural resources to sustain itself. These include the longest coast in Africa, two permanent rivers (Jubba and Shabelle), millions of acres of cultivable land and millions of livestock. There are also rumours of abundant oil and natural gas. In fact, prior to 1972, Somalia used to feed its own people and had surplus grain that was exported. However, because of the bad economic policies of the government of Siad Barre, the country became a net importer of grain by 1975. Second, there is the diversity among the Somalis in the diaspora, who have married foreigners and given birth to children in other countries. Some changed their religion and others their sexual orientation. Today about 750,000 (7\%) of the Somali population live abroad and many of them have created large and thriving communities in prosperous countries including South Africa, Canada, United States and the United Kingdom.

Since the mid 1970s, the diaspora community has been the backbone of the collapsed Somali economy through remittance and in some cases investments. For example, the World Bank estimates about US \$750,000 annually are remitted by the diaspora communities using an informal system called Hawala. ${ }^{29}$ The most important benefit of the diaspora, however, is not the remittance, but rather the hard work, education, saving and in some cases the humiliation they experience in their host countries, all of which can help to provide the basis for a future stable and prosperous Somalia. Many Somalis in the diaspora, including the

29 For more details on Hawala, see the UNDP report (UNDP 2006)

http://www.so.undp.org/Remittance/ssp-hawala.pdf 
author, are ready to repatriate for they understand the meaning of being a citizen. Currently, there are movements in the diaspora, especially in North America, that are very influential. For example, in the latest round between the Islamic Courts and transitional government the community has written petitions to both sides and for the first time they are willing to use economic sanctions. Unlike the earlier times when the diaspora was entirely influenced by the rigid and unchanging clanism; this new breed of the diaspora have understood that after all they are strangers in foreign lands without the claim to nobility that has blinded many Somalis before leaving their country.

In closing, the Somali cultural diversity can be a uniting force or a dividing and deadly force, and we need to come up with ways to utilise it for the good. One effective way is first to address and solve past wrongs that were committed against mainly the sedentary communities in Southern Somalia; secondly to conduct a fair and impartial census that will in the future determine a fair, representative and balanced political system, and finally to bring the wealth and knowledge of the diaspora by creating a conducive environment that accommodates diversity including religion, language and opinion and establishing the rule of law. After all, the recovery of Lebanese society from their years of civil war has been greatly facilitated and expedited by its diaspora community.

\section{Sources}

Adedeji, Adebayo 1999. Comprehending African Conflicts, in Adedeji (ed), Comprehending African Conflicts: The Search for Sustainable Peace and Good Governance. London: Zed Books.

Ahmed, Ali Jimale 1995. Daybreak is Near, Won't You Become Sour, in Ahmed, Ali Jimale (ed), The Invention of Somalia. Lawrenceville, NJ: Red Sea Press, Inc.

Ayittey, George B.N. 1994. The Somali Crisis: Time for an African Analysis. Policy Analysis, No 205, March 28.

Bayart, Jean-François 1993. The State in Africa: The Politics of the Belly. New York: Longman.

Berman, Bruce 1998. Ethnicity, Patronage, and the African State: the Politics of Uncivil Nationalism. African Affairs 97 (July), 305-341. 
Besteman, Catherina 1999. Unraveling Somalia: Race, Violence, and the Legacy of Slavery. Philadelphia: University of Pennsylvania Press

Braathen, Einar, Morten Bøås \& Gjermund Sæther 2000. Ethnicity Kills? Social Struggles for Power, Resources, and Identities in the Neo-Patrimonial State, in Braathen, Einar, Morten Bøås \& Gjermund Sæther (eds), Ethnicity Kills? The Politics of War, Peace and Ethnicity in Sub Sahara Africa. New York, NY: St. Martin Press

Brass, Paul 1985. Ethnic Groups and the State. London: Croom Helm.

Brautigam, Deborah 1996. State Capacity and Effective Governance, in Ndulu, Benno \& Van de Walle, Nicolas (eds), Agenda for Africa's Economic Renewal. Washington, DC: Overseas Development Council.

Brubaker, Roger 1995. National Minorities, Nationalizing States, and External National Homelands in the New Europe. Daedalus Spring, 107-132.

Casanelli, Lee V. 1982. The Shaping of the Somali Society. Philadelphia: University of Pennsylvania Press.

Casanelli, Lee V. \& Besteman, Catherina L. 1996. The Struggle for Land in Southern Somalia: The war behind the war. Colorado: Westview.

Chazan, Naomi, Lewis, Peter, Mortimer, Robert, Rothschild, Donald \& Stedman, Stephen 1999. Politics and Society in Contemporary Africa. $3^{\text {rd }}$ Edition. Boulder: Lynne Rienner.

Clapham, Christopher 1988. Rwanda: The Perils of Peace Making. Journal of Peace Research Vol. 35 (2), 193-210.

Connor, Walker 1994. Ethnonationalism: The Quest for Understanding. Princeton. NJ: Princeton University.

Ekeh, Peter P. 1975. Colonialism and the Two Publics in Africa: A Theoretical Statement. Comparative Studies in Society and History 17 (1), 91-112.

Elbadawi, Ibrahim A. \& Sambanis, Nicholas 2000. External Interventions and the Duration of Civil Wars. World Bank, Development Research Group, Public Economics.

Ethnologue 2006. http://www.ethnologue.com/show country.asp?name=SO accessed 15 Feb 2006.

Eyoh, D. 1995. From the Belly to the Ballot: Ethnicity and Politics in Africa. Queen's Quarterly 102 (1), 39-51.

Forsyth, Frederick 1977. The Making of an African Legend: The Biafra Story. New York: Penguin Books.

Geertz, Clifford 1973. The Interpretation of Cultures. New York: Free Press.

Gurr, Ted Robert \& Harff, Barbara 1994. Ethnic Conflict in World Power. Boulder, CO: Westview Press.

Hagi, A.O. \& Hagi, A.O. 1998. Clan, Sub-clan and Regional Representation in the Somali Government Organization 1960-1990. Statistical Data and Findings. USA

Hashim, Alice 1997. The Fallen State: Dissonance, Dictatorship and Death in Somalia. Lanham: University Press of America. 
Herbst, Jeffrey 2000. States and Power in Africa: Comparative Lessons in Authority and Control. Princeton, NJ: Princeton University Press.

Horowitz, Donald 1985. Ethnic Groups in Conflict. Berkeley, CA: University of California Press.

Human Rights Watch 2006. http://www.hrw.org/reports/1993/somalia/\#P68_12775\#P68_12775 accessed 15 Oct 2006.

Hutchful, Eboe 2000. Understanding the African Security Crisis, in Abdel-Fatau, Musah \& Fayemi, J.'Keyode (eds) Mercenaries: An African Security Dilemma. London: Pluto Press.

Jackson, Robert H. 1992. Juridical Statehood in Sub-Saharan Africa. Journal of International Affairs 46 (1).

Kaplan, Robert D. 1993. Balkan Ghosts: A Journey Through History. New York: St Martin.

Keen, David 1998. The Economic Functions of Violence in Civil Wars. Adelphi Paper 320, London: IISS.

Kuran, Timur 1998. Ethnic Dissimilation and Its National Diffusion, in Lake, David A. \& Rothschild, Donald (eds), The International Spread of Ethnic Conflict: Fear, Diffusion, and Escalation, 35-60. Princeton, NJ: Princeton University Press.

Kusow, Abdi 1994. Peace and Stability in Somalia: Problems and Prospects. UFAHAMU. XXII (I \& II).

Laitin, David \& Samatar, Said 1987. Somalia: A Nation in Search of State. Boulder: Westview Press.

Lake, David A. \& Rothschild, Donald 1998. Spreading Fear: The Genesis of Transnational Ethnic Conflict, in Lake, David A. \& Rothschild, Donald (eds), The International Spread of Ethnic Conflict: Fear, Diffusion, and Escalation, 3-32. Princeton, NJ: Princeton University Press.

Lefebvre, Jeffrey A. 1991. Arms for the Horn: U.S. Security Policy in Ethiopia and Somalia, 1953-1991. Pittsburgh: University of Pittsburgh Press.

Leonard, David K. \& Strauss, Scott 2003. Africa's Stalled Development: International Causes and Cures. Boulder, CO: Lynne Rienner.

Lewis, Bernard 1992. Muslims, Christians, and Jews: The Dream of Coexistence. New York Review of Books. March, 26 p. 48.

Lewis, I.M. 1955. Peoples of the Horn of Africa. London: International Affairs Institute.

Lewis, I. M. 1961. A Pastoral Democracy: A Study of Pastoralism and Politics Among the Northern Somali of the Horn of Africa. London: Oxford University Press.

Lewis, I. M. 1980. A Modern History of Somalia: Nation and State in the Horn of Africa. London: Longman.

Lewis, I.M. 2007. Cultural Orientation Resource Center. http://www.culturalorientation.net/somali/ssoc.html accessed 10 Jan 2007.

Lijphart, Arend 1977. Democracy in Plural Societies. New Haven, Conn.: Yale University Press. 
Makinda, Samuel M. 1993. Seeking Peace from Chaos: Humanitarian Intervention in Somalia. Boulder: Lynne Rienner.

Mamdani, Mahmood 1996. Citizen and Subject: 1960 Contemporary Africa and the Legacy of Late Colonialism. Princeton NJ: Princeton University Press.

Mamdani, Mahmood 2001. When Victims Become Killers: Colonialism, Nativism and the Genocide in Rwanda. Princeton, NJ: Princeton University Press.

Médard, Jean-Francois 1996. Patrimonialism, Neopatrimonialism and the Study of the Postcolonial State in Sub-Saharan Africa, in Marcussen, H. S. (ed), Improved Natural Resource Management: the Role of Formal Organisations and Informal Networks and Institutions, 76-97. Roskilde: Roskilde University Press.

Mubarak, Jamil Abdalla 1996. From Bad Policy To Chaos in Somalia. Westport, CT: Praeger Publishers.

Mukhtar, Mohamed H. 1989. The Emergence and the Role of Political Parties in the InterRiverine Region of Somalia from 1947 to 1960 (Independence). UFAHAMU: Journal of the African Activist Association XVII (II), 57-69.

Mukhtar, Mohamed H. \& Kusow, Abdi 1993. Bottom-up Approach in Reconciliation in the Inter-river Regions of Somalia. A Visiting Mission Report, Aug 18-Sep 23, 1993.

Odetola, Olatunde 1982. Military Regimes and Development. London: George Allen \& Unwin.

Osman, Abdulahi A. 2006. The Somali Conflict and the Role of Inequality, Tribalism and Clanism. African Renaissance 3 (5) Sep/Oct, 74-82.

Osman, Abdulahi A. 2007. Governance and Internal Wars in sub Saharan Africa: Exploring the Relationship London: Adonis \& Abbey.

Ottaway, Marina 1982. Soviet and American Influence in the Horn of Africa. New York: Praeger.

Ottaway, Marina 1999. Ethnic politics in Africa: Change and Continuity, in Joseph, Richard (ed), State, conflict, and Democracy in Africa, 229-318. Boulder, CO: Lynne Rienner.

Posen, Barry 1993. The Security Dilemma and Ethnic Conflict, in Brown, Michael E. (ed), Ethnic Conflict and International Security, 103-124. Princeton, NJ: Princeton University Press.

Rodney, Walter 1977. How Europe Underdeveloped Africa. Washington, DC: Howard University Press.

Samatar, Ahmed I. 1988. Socialist Somalia: Rhetoric and Reality. New York, NY: Zed Press.

Samatar, Ahmed I. 1993. Undersiege: Blood, Power, and the Somali State, in Nyong'o, P. Anyang', Arms and Daggers in the Hearts of Africa, 67-100. Nairobi: Arrucian Academy of Science.

Samatar, Ahmed I. 1994. The Somali Challenge from Catastrophe to Renewal. Boulder: Lynne Rienner.

Samatar, Said \& Laitin, David 1984. Somalia: A Nation in Search of State. Boulder, Colorado: Westview Press. 
Shills, Edward 1957. Primordial, Personal, Sacred and Civil Ties. British Journal of Sociology 7, 13-45.

Steinberg, Stephen 1981. The Ethnic Myth; Race, Ethnicity and Class in America. New York: Athenium.

Stewart, F. \& Fitzpatrick, Gerald E. 2001. The Economic and Social Consequences of Conflict. Oxford: Oxford University Press.

Touval, Saadia (1963). Somali Nationalism. Boston: Harvard University Press.

United Nations Development Program (UNDP) 2006.

http://www.so.undp.org/Remittance/ssp-hawala.pdf accessed 1 Oct 2006.

Young, Crawford 1994. The African Colonial State in Comparative Perspective. New Haven, CT: Yale University Press. 